\title{
How to Align and Unify the Cell Counting of Organisms for Bioindication
}

\author{
*Sophia Barinova \\ Institute of Evolution, University of Haifa, Israel
}

Submission: April 23, 2017; Published: April 27, 2017

*Corresponding author: Sophia Barinova, Institute of Evolution, University of Haifa, Mount Carmel, 199 Abba Khoushi Ave, Haifa 3498838, Israel, Email: sophia@evo.haifa.ac.il

\begin{abstract}
Paper represented the new preparation method that involves maximal and adequate species content from the natural community sample for both, soft and diatom algae together. The unified system of the algal cells estimation is represented for different samples of natural algal communities such as plankton, periphyton or algal benthic inhabitants. New methods of preparation and estimation can improve and simplify the work with multi-specific and abundant communities of microscopic algae for bioindication purposes. Now the pollution indices calculation of which is recommended for pollution impact assessment can be estimated on the base not only diatom algae but also with other species of soft algae that are widely represented in aquatic communities of countries from southern regions.
\end{abstract}

Keywords: Bioindication; Algae; Aquatic ecosystem; Indices

\section{Introduction}

Pollution in the freshwater aquatic objects is complicated system of problems and methods for dissolved of the problem how summarizes information about environment and biota that can be classified for pollution impact assessment. The mutual influence of the diversity of freshwater algae and their habitat ecology of the species is determined, developing in the study community. The basis of the principle is of bioindication compliance the community composition to the parameters of its habitats classification of which can represent continuously unified system [1]. Because the advanced systems of bioindication are based on the pollution indices calculation, we must give more attention to the abundance of each species calculation. It is known few systems for abundance assessment for different purposes.

\section{The Algal Samples Preparation for Future Estimation}

The algal community is usually represented in the sample of phytoplankton or phytoperiphyton when collected from the natural or experimental habitats. The major purpose for the bioindication is to include maximal species content from the algal samples. Few methods of sample collection are cut off possibility for algal species definition such as the Lugol's solution fixation that colored algal cells to orange and mask some important properties for species definition. Another problem is preparation of different groups of soft algae and diatoms by different methods. For example, the natural algal sample usually divided into two parts in one part of which are identified soft algae from one drop of sample under light microscope but the other part of sample is undergoes processing by the acid or peroxide methods for organic cleaning from the frustules. Both methods give the algae slides for estimation of species abundance but in different system each. So, soft algae usually counted in the score systems (5-11 scores) but diatom species are defined under high resolution microscopes and SEM and counted as percent of each species abundance.

Nevertheless, slides are prepared from one sample of natural community, we cannot summarize the estimation results but the species list only. It gives us two ways for the species contain and estimation results using for bioindication. The first is different using the estimation results for soft and diatom algae. That cut off about half of species content from each soft and diatom way of bioindication. But we declared earlier that all possible defined species can be represented in the bioindication assessment because this way represent most adequate response of algal community to the environment in which it was taken.

The second problem is the latitude of habitat from which algal sample was collected. It looks like not important things because the algae are mostly represented by cosmopolitan species but our experience of bioindication in aquatic objects in different latitude of Eurasia is demonstrated species contain changes with latitude of habitat [2-4]. More of them, the vast majority of pollution indices are developed on the species of 
diatoms. Of course, this group is well studied with respect to taxonomy and morphology but there is a problem that diatoms are well represented in the aquatic communities of European countries-developers, related to the boreal zone. When we explore communities in more southern regions, such as in our experience in Ukraine, Turkey, Pakistan, India or Israel, we are faced with the fact that diatoms represents only a relatively small part of the communities, but green algae and cyanobacteria are more widely represented $[1,4,5]$.

In purpose to improve the estimation of species cells from algal community slides for bioindication, the new combined method for preparation is presented.

a. Sample of algal community can be living or fixed by the formaldehydes neutral solution about 2-4\%.

b. One drop of algal sample takes and places into the slide glass, covered by cover glass and study under microscope with relevant technique such as oil immersion. Soft algal species or some large-shells diatom are defined and its cells counted with percentage or scores methods.

c. One drop of algal community sample takes and places into the cover glass. The cover glass with algal drop in up is placed on a hot plate with a temperature of about $100^{\circ} \mathrm{C}$ and the water from the drop is slightly evaporated. Then, concentrated to about $30 \%$ hydrogen peroxide is added to the wet drop on the glass, gradually evaporated. The digestion of hydrogen peroxide is repeated several times before evaporation. The quality of cleaning the diatom shells from organic matter is checked under a microscope. Processing on one glass is repeated until all of the organic material has dissolved and the solution evaporates. d. It is important to use only concentrated and only hydrogen peroxide, since the products of its disintegration in the treatment of the preparation are water and carbon dioxide, which evaporate without leaving a crystals on the preparation.

e. The cover glass with the cleaned shells of the diatoms is turned over by a layer of shells downwards and placed into the mountain for permanent preparations, such as Naphrax or Canadian Balsam.

f. The diatom species are identified under microscope with relevant technique and handbooks.

g. Calculation of diatom shells can be doing in both systems, percentage and scores but in both ways it can be the same as was used for the soft algae calculation. In any case, we can take in mind that the shells are represent only one half of diatom cell, therefore the result of the diatom shells calculation should be divided into two for represent some real unicellular diatom species in community.

h. Both results of definition and calculation in soft and diatom slides can be combined into a common list for treated community in purpose of future bioindication.

i. As a result, we have the unified list of species that represent all algal diversity from studied community with abundance scores or percentage that relevant to the natural sample of community. Usually we can define and estimate about $90 \%$ of cells in the slides. That give us large opportunity for study the species proportions in community as well as bioindication methods.

\section{The Unified System of Algal Abundance Estimation}

Table 1: Species frequencies according to 5-9-scores scales according to [6].

\begin{tabular}{|c|c|c|c|c|c|c|}
\hline 9-Score & 6-Score & 5-Score & Visual Estimate & $\begin{array}{l}\text { Cell numbers of } \\
\text { plankton per } L\end{array}$ & $\begin{array}{l}\text { Cell numbers of } \\
\text { periphyton per slide } \\
(20 \times 20 \mathrm{~mm})\end{array}$ & $\begin{array}{c}\text { Cell number of each } \\
\text { species, } \%\end{array}$ \\
\hline 1 & 1 & 1 & Occasional & $1-10^{3}$ cell $\mathrm{L}^{-1}$ & 1-5 cells per slide & $<1$ \\
\hline 2 & 2 & 2 & Rare & $10^{3}-10^{4}$ cell L ${ }^{-1}$ & 10-15 cells per slide & $2-10$ \\
\hline 3 & 3 & 3 & Common & $10^{4}-10^{5} \mathrm{cell} \mathrm{L}^{-1}$ & 25-30 cells per slide & $10-40$ \\
\hline 5 & 4 & 4 & Frequent & $10^{5}-10^{7}$ cell $\mathrm{L}^{-1}$ & $\begin{array}{l}1 \text { cell over a slide } \\
\text { transect }\end{array}$ & $40-60$ \\
\hline 7 & 5 & 4 & Very frequent & $10^{6}-10^{7}$ cell L $\mathrm{L}^{-1}$ & $\begin{array}{l}\text { Several cells over a } \\
\text { slide transect }\end{array}$ & $60-80$ \\
\hline 9 & 6 & 5 & Abundant & $\begin{array}{l}\text { More than } 10^{7} \text { cell } \\
\mathrm{L}^{-1}\end{array}$ & $\begin{array}{l}\text { One or more cells in } \\
\text { each field of view }\end{array}$ & $80-100$ \\
\hline
\end{tabular}

The algal abundances (Table 1) can be assessed based on a 6-score scale [6] and used for calculating the saprobitys indices by Sládeček [7]. The 5-score scale [8] was applied to calculate the EPI (Environmental Pollution Index) according Dell Uomo [9]. It is used also as calculation of percentage in the treated samples, and this method is very distributed. In (Table 1) can be seen that all methods can give us some information about cell numbers in the sample square or volume. The table we created based on few wildly used methods of frequency estimation. Now, if we have some calculation of cell numbers for the slide square, we can approximately assume the cell number in the volume and vice versa. In our practice, it can be helps for comparison of different indices and data from the references. 
Why we said cell number of each species. Yes, of course, the frequency can be estimated as the number of coenobia or cell aggregates if the organism is colonial. However, the aggregates count can only help to calculate fast and have not ecosystem importance properties. In any case, we can assess the number of individuals that for algae and cyanobacteria in freshwaters is the cell number. It is especially important for the Shannon diversity indices calculation because its values is interpreted as the complicity of the biotic part of ecosystem but different approaches to index calculation gives very incomparable data.

The second question that is very important to understand is how to use the maximal revealed algal diversity in the samples. The water quality indices were mostly created in the countries, which are placed in the Boreal Realm. That means that the algal community from water bodies of these climatic and biogeographically zones is represented mostly by diatom species. Yes, of course, the bioindication and indices calculation must be based on the most part of the community. Therefore, we try to define and estimate all possible cells for this purpose. But, it is problem to calculate only diatoms when our community is from the southern regions. As was mentioned above, we describe the algal slides preparation method for adequate calculation of soft and diatom algal cell together with precision species definition that is the main request of bioindication.

\section{Conclusion}

The combination of new preparation method that involve maximal and adequate species content from the natural community sample for soft and diatom algae with the new of algal cells estimation approach is represented. A new method can improve and simplify the work with multi-specific and abundant communities of microscopic algae for bioindication purposes. Thus, bioindication methods recommended [10] and used [11] in advanced monitoring systems can be enriched and improved using a wider species composition of the algal community. Now the pollution indices calculation of which is recommended for pollution impact assessment can be estimated on the base not only diatom algae but with other species of soft algae that are widely represented in aquatic communities of countries from southern regions. More of it, the aquatic ecosystem state and water quality assessment with implementation of given methods of abundance of algal cells calculation can be used together with earlier represented [1] classification system from ecological point of view and indices in the implementation of which we have many positive examples of using in the diverse aquatic ecosystems of Eurasia [2,5,6].

\section{Acknowledgement}

This work has been partly supported by the Israeli Ministry of Absorption.

\section{References}

1. Barinova S (2017) On the Classification of Water Quality from an Ecological Point of View. Int J Environ Sci Nat Res 2(2): 1-8.

2. Barinova S, Gabyshev V, Gabysheva O (2014) Climate impact of freshwater biodiversity: general patterns in extreme environments of North-Eastern Siberia (Russia). British Journal of Environment and Climate Change 4(4): 423-443.

3. Barinova $S$ (2011) The effect of altitude on distribution of freshwater algae in continental Israel. Current Topics in Plant Biology 12: 89-95.

4. Barinova S, Krassilov VA (2012) Algal diversity and bio-indication of water resources in Israel. International Journal of Environment and Resource 1(2): 62-72.

5. Barinova S (2011) Algal diversity dynamics, ecological assessment, and monitoring in the river ecosystems of the eastern Mediterranean. Nova Science Publishers, New York, USA, pp. 363.

6. Barinova SS, Medvedeva LA, Anissimova OV (2006) Diversity of algal indicators in environmental assessment. Pilies Studio, Israel.

7. Sládeček V (1973) System of water quality from the biological point of view. Arch Hydrobiol 7: 1-218.

8. Whitton BA, Roth E, Friedrich G (1991) Use of algae for monitoring rivers. Institutfur Botanik Univ Press, Innsbruck, Austria, pp. 191.

9. Dell Uomo A (1996) Assessment of water quality of an Apennine river as a pilot study for diatom based monitoring of Italian watercourses. In: Whitton BA and E Rott (Eds), Use of algae for monitoring rivers II, Institutfur Botanik Univ Press, Innsbruck, Austria, p. 65-72.

10. European Parliament (2000) Directive 2000/60/EC of the European Parliament and of the Council establishing a framework for community action in the field of water policy. OJL 327: 1-72.

11. UNEP/IPCS (2006) Training Module No 3 Section C Ecological Risk Assessment. Edinburgh Centre for Toxicology, Scotland.
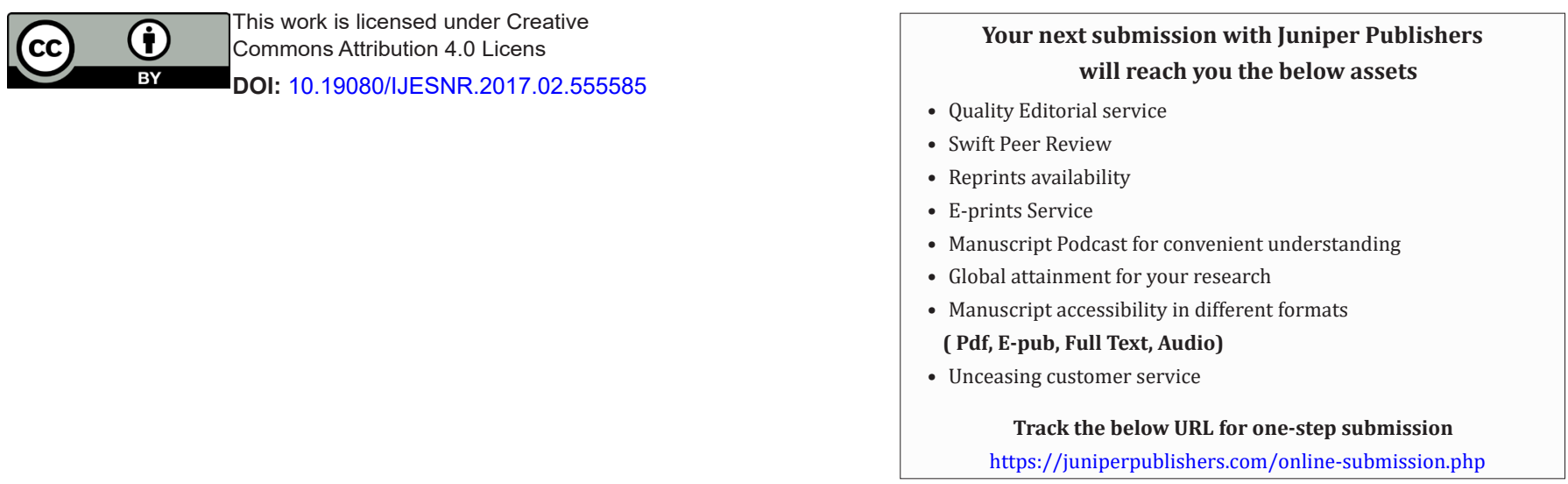